\title{
The Politics of Anticipation: On Knowing and Governing Environmental Futures
}

Céline Granjou ${ }^{\mathrm{a}}$, Jeremy Walker ${ }^{\mathrm{b}}$ and Juan Francisco Salazar ${ }^{\mathrm{c}}$

\author{
${ }^{\text {a }}$ Corresponding author. \\ IRSTEA Grenoble- University of Grenoble-Alps \\ UMR PACTE \\ Interdisciplinary Laboratory on Science, Innovation and technology LISIS \\ Address: \\ IRSTEA- 2 rue de la Papeterie BP 76 \\ 38400 St Martin d'Heres, France. \\ celine.granjou@irstea.fr \\ ${ }^{\mathbf{b}}$ University of Technology Sydney \\ Social and Political Sciences, Faculty of Arts and Social Science \\ PO Box 123 Broadway NSW, 2007, Australia \\ jeremy.walker@uts.edu.au \\ ${ }^{\mathbf{c}}$ Western Sydney University \\ Institute for Culture and Society \\ Parramatta, NSW 2150, Australia. \\ j.salazar@westernsydney.edu.au
}

\begin{abstract}
In this article we describe how the historical emergence and rise of future studies, since the founding issue of Futures in 1967, has been intricately connected to the emergence and development of environmental anticipation as discourse and practice. We trace a dialectical and inter-twined relationship between technologies of environmental anticipation and forecasting, and technologies of anti-environmentalist anticipation and intervention, one which we argue has shaped the contemporary politics of anticipation, and in a very material sense, continues to shape the future of biological and social life on Earth. In so doing we want to critically address the very contrasted contributions that the field of futures studies can make to collective agency and to reimagining collective ways of being on Earth. The article also introduces this special issue of Futures on "The Politics of Environmental Anticipation" with the aim to bring to the fore the role that social scientists play in environmental anticipation - ie. drawing attention to the fact that the future could always have been otherwise. As a whole, this stimulating collection of eight original articles provides a critical assessment of a range of sites where varied and conflicting politics of environmental anticipation get constituted and resisted.
\end{abstract}

Keywords: anticipation; global environmental change; future studies 


\section{Introduction}

\section{"Hell is truth seen too late"}

Attributed by some to the political philosopher Thomas Hobbes and by others to the philosopher of history Georg W. Hegel, this apocryphal aphorism might be said to define the existential terrain of the cross-discipline of future studies. A relatively young social science arising from modern forms of political, scientific, technological and economic organisation, the arts and sciences of anticipation are engaged with a wide array of knowledge traditions and practices which seek to answer with foresight the existential danger of seeing the way things are only with hindsight - when it is too late.

Ideas of the future inform action in the present, and ways of knowing, forecasting, and actively anticipating future events are crucial elements of social organisation. Yet systematic attention to the future (and the social production of fore-knowledge) has often been limited to the margins and interstices of the human and social sciences, which have tended to concentrate on the immediate present as an outworking of historical patterns past. In this article we argue that if anything has truly revolutionised the anticipatory human and social sciences it is the emergence of the political horizon of anthropogenic ecological risks on a planetary scale. The historical emergence and rise of future studies has been intricately connected to the emergence and development of the dialectical and intertwined relationship between technologies of environmental anticipation and forecasting and technologies of anti-environmentalist anticipation and intervention. This dialectical movement is still shaping the contemporary politics of anticipation of the future of biological and social life on Earth.

\section{I- The co-emergence of future studies and the politics of environmental anticipation}

As we race through the threshold of an 'urban climacteric' (Davis, 2006, p.1) the majority of the worlds' human populations now live and act in urban spaces. In this context practices of bringing the future into the present and shaping the present to anticipated futures take socio-material form in the complex architectures and infrastructures of everyday life: in the communication networks carrying flows of finance, information, and entertainment; in energy grids and the hydro-social spaces of water and sewage; in transport conduits that connect agro-industries with mines, and sweatshops with markets. For most people, the immediate 'environment' is an infrastructured life-world integrated into the planetary expansion and intensification of global "industrial technomass": a "dissipative structure" in thermodynamic terms (Hornborg, 2001, p.87), which maintains its order, motion and growth through a systematic conversion of 'natural resources' into myriad novel artefacts and waste flows, a process thus far largely driven by the energy released in the irreversible combustion of eons of fossilised photosynthesis.

Few could disagree that the horizon of future studies has expanded in significant ways since the rise of the 'ecology movement' in the late 1960's: chemical, radiological, plastic and nutrient pollution; abrupt climate change, runaway global warming of the atmosphere and land surfaces; melting of polar ice shelves and sea level rise; ocean acidification, mass biodiversity extinction, and health threats from zoonotic, food-borne and emerging infectious diseases all mean the end of the idea of nature as an inert, unchanging backdrop to the drama of human affairs. In other words, the concern with environmental futures and the politics of anticipation of future environments and socio-ecological relations is critically different from the time of the first United Nations Conference on the Human Environment in 1972 when environmental futures arguably became an official matter of concern globally for the first time.

When the first issue of Futures appeared in 1968, an interest in disciplined foresight was becoming apparent across a range of fields, particularly in economics, political science, business management and the geophysical sciences. Futures studies only began forming in the mid-1960s as an academic 
discipline- or perhaps more aptly, as a trans disciplinary field without a distinct core centre. Among the key moments in this crystallisation of futures studies was the formation of the World Futures Studies Federation (WFSF) in 1967, and the publication of such works as Bertrand de Jouvenel The Art of Conjecture (1967), Alvin Toffler's Future Shock (1970) among many others - too numerous to name here -which were debating in one way or another the accelerating change that for liberalconservative scholars such as Daniel Bell, augured The Coming of Postindustrial Society (1973). For Bell, the postindustrial future would arise from the mastery of nature manifest in the harnessing of atomic energy and the rapid development of digital computers and communcation technologies. $\mathrm{He}$ took dismissive note of the nascent environmental movement:

"[...] ecological reformers like Rachel Carson and Barry Commoner, [...] invoke the institutional charisma of science in making moral or political judgments. What we have here is the resumption of the prophetic claims of science in setting forth truth as against self-interest. [...] Paradoxically, the vision of Utopia - a fully automated production economy with an endless capacity to turn out goods - was suddenly replaced by the spectre of Doomsday. In place of the early-sixties theme of endless plenty, the picture by the end of the decade was one of a fragile planet of limited resources whose finite stocks were rapidly being depleted, and whose wastes from soaring industrial production were polluting the air and waters. Now the only way of saving the world was zero growth. What was striking in this change is the shift in attention from machinery to resources, from man's mastery of nature to his dependence on its bounty, from Harrod-Domar-Solow growth economics to Malthusian-Ricardian scarcity economics. And the principle of diminishing returns, rather than increasing returns to scale, becomes the analytical motif." (Bell, 1976, p. 404)

It's probably not reasonable, nor possible, to undertake a comparison between the state of affairs in 1967 and 2017. The world - and the future for that matter - has changed quite significantly in the past 50 years. In fact, the future seems to have changed dramatically in 2016 as this special issue of Futures was being put together. In early 2016 the Paris Agreement (accorded at COP 23 in December 2015) opened for signature on at a ceremony in New York on April 22 (Earth Day). By December 2016 it had been signed by 194 UNFCCC members. One month later Donald Trump was inaugurated as President of the United States, who in his first month in office warned of pulling out of Paris agreement, whilst appointing Rex Tillerson, CEO of ExxonMobil, as Secretary of State.

"It its crystal clear that the foundations of our free society are under wide ranging and powerful attack - not by Communists or any conspiracy but by misguided individuals parroting one another and unwittingly serving ends they would never intentionally promote."

The Powell memorandum outlined a pervasive long term strategy, calling upon American corporations "at all levels and at every opportunity, to be far more aggressive than in the past," to organise and generously fund a para-academic network of pro-business scholars, lawyers, advertisers and public communiations professionals to capture the commanding heights of public opinion through the popular media, and influence state policy formation wherever possible. In 1972, business corporations responded to the threat with the formation of the Business Roundtable, a powerful federal lobby group of the CEOs of the 200 largest transnational corporations. In 1973, wealthy donors and corporate interests established the Heritage Foundation to promote bold social and environmental deregulation. It is but one of the contemporay galaxy of neoliberal thinktanks among whose founding

\footnotetext{
${ }^{1}$ Friedman cited in Lewis F. Powell, 'Attack on American Free Enterprise System. Memorandum to Eugene B. Sydnor, August 23, 1971'. http://law2.wlu.edu/deptimages/Powell\%20Archives/PowellMemorandumTypescript.pdf
} 
aims, as one contributor to the Heritage Foundation house journal put it, was to "strangle the environmental movement" (Andrews et al, 1990; Layzer, 2012). ${ }^{2}$

Given the central role of oil companies in organising epistemic and political resistance to frustrate climate policy it's a historical irony that the Shell Research division sponsored the atmospheric chemist James Lovelock to develop the seminal papers that introduced 'Gaia theory' - which foregrounds the transformative role of global biological processes in maintaining the thermal and geochemical conditions conducive to life on earth to the scientific and public imagination (Margulis \& Lovelock, 1974; Lovelock \& Margulis 1974). As the 'Exxon papers' gathered by the divestment committee of the Rockefeller Family Fund reveal, Exxon sponsored extensive global climate change research from the 1970s. In something of a historical irony given the origins of both Exxon and the Rockefeller fortune in John D. Rockerfeller's Standard Oil monopoly, the Fund targeted ExxonMobil for immediate divestment because of its "morally reprehensible conduct": a 25 -year-long campaign to deceive policymakers and the public about the realities of fossil fuel combustion and climate change, "protecting its profits at the cost of immense damage to life on this planet" (Kaiser \& Wasserman, 2016). In full knowledge of the abiding scientific consensus linking fossil fire to global heat accumulation, which their own researchers suggested could result in a rise of the average temperature of the earth by $6^{\circ} \mathrm{C}$ this century's end, Exxon decided to pursue a political strategy that could be termed 'anticipatory agnotology'. "We should determine", wrote one executive in 1982,

"how Exxon can best [..] influence possible legislation on environmental controls. It is important to begin to anticipate the strong intervention of environmental groups and be prepared to respond with reliable and credible data." (in Kaiser \& Wasserman, 2016).

Even without the threats posed by the Trump administration to the future the Paris Agreement, the problem remains, as Rockström et al have bluntly put it, that the "scale of the decarbonisation challenge to meet the Paris Agreement is underplayed in the public arena" (2016, p.465). It's the world's biggest gamble, one which may foreclose on the time allowed for recognisable life on Earth, as Rockström et al contend:

It will require precipitous emissions reductions within 40 years and a new carbon sink on the scale of the ocean sink. Even then, the world is extremely likely to overshoot. A catastrophic failure of policy, for example, waiting another decade for transformative policy and full commitments to fossil-free economies, will have irreversible and deleterious repercussions for humanity's remaining time on Earth (2016, p.465).

If we were pressed to nominate a signal event marking the advent of modes of future orientation that might be regarded as indelibly modern, it might be a decree issued five centuries ago by the Roman Catholic Church, at the Fifth Lateran Council in 1517. Later this year Martin Luther would nail his critique of the Church to one of its doors. This was a time when the rapid multiplication of vernacular texts enabled by the printing press - many written in the political eschatology characteristic of social movements anticipating revolutionary social change - had circumvented the Church's Latin-based ecclesial monopoly on knowledge. Hand-written drafts of the Polish astronomer Nicolaus Copernicus' heliocentric world systems theory were secretly in circulation amongst his intellectual peers (Koyré, 1973, p. 85). The scientific revolution was underway and with it would emerge a wholly new, posttheological ontology of time and space, which the philosopher of science Alexandre Koyré would characterise as a cosmo-philosophical transition From the Closed World to the Infinite Universe

\footnotetext{
${ }^{2}$ For the most comprehensive mapping of the think tank network, see the global directory of the Atlas Network. Founded as the Atlas Foundation in 1981 by Antony Fisher, a disciple of Friedrich Hayek who became wealthy through pioneering intensive battery-farming methods in the poultry industry, the Atlas Network coordinates policy, personnel and funding across 465 think tanks in 95 countries. https://www.atlasnetwork.org/partners/global-directory
} 
(1957). At the Council, the Church asserted its sole domain over prophecy and the temporal order of Creation through to the Kingdom to Come, formalising a doctrine that beforehand had only been tacitly assumed: "claims about the future of the world must be authorised by the Church". Paul Rabinow has described Christendom's history as "a history of expectations, or more exactly, the constant anticipation of the End of the World on the one hand and the continual deferment of the End on the other" $(2003$, p.59). The thrones and powers of our own era, it might be said, are in a similar state of dialectical struggle over the authority to declare and make the future, although now, not in the terms of Divine cosmogony, rather in terms of the challenges to social and economic organisation posed by the scientific analysis of ecological devastation past, present and yet to come.

The modern era would (partially) secularize European religious millennialism into the grand ideologies of infinite Progress, to be achieved here on Earth through rational government, social organisation, and and the 'conquest of the material world' through industrial technoscience. Scholars who celebrated industrialism as the triumph of human understanding, such as the industrial historian John Nef (1964), tended to stress the fundamental role of heavy industry and the 'coming of the industrial state' to the non-European world as the key driver of historical change. For the industrial historian John Nef, this process represented nothing less than The Conquest of the Material World (1964), something of a pyrrhic victory from the vantage point of the present.

As the fossil-fuelled pyrotechnical industries - fossil capital (Malm, 2016) at large - have come ever more to determine the political economy of liberal-democratic 'carbon democracies' and their, authoritarian oil-rich satellite states (Mitchell, 2011), the progressive social philosophies of Enlightenment humanism have increasingly yielded influence to a more banal, yet equally unshakeable commitment. To Progress as infinite economic growth as measured in monetary GDP statistics, first pursued internationally through 'Keynesian', and since, by neoliberal economic policies. If the orthodox, institutional social sciences still cleave to visions of the Millennium, of a coming generalised 'age of high mass consumption' in which permanent growth in production and consumption has become the normal condition (Rostow, 1960) it has fallen to the sober rationalism of the natural sciences to counter this exuberant public theology of costless abundance. Paradoxically, indirectly, it is to biologists, chemists, physicists and earth scientists that we may attribute much of the 'apocalyptic tone recently adopted in philosophy' - to parse Derrida (1984) parsing Kant, the philosopher of Progress par excellence. Eschatology, according to Hans Blumenberg (1985, p.30), speaks of an 'event breaking into history'. It would be hard to imagine a more profound ly example of such an onto-theological challenge to the home truths of industrial modernity than the manifold revelations of the destructive consequences immanent in the structure of our everyday practices.

\section{II- Living in a state of anticipation: historical and new challenges for the social sciences}

The set of questions that social scientists and futures scholars today address may still have largely to do with the modalities through which the environmental futures - as contingent sets of possibilities are made present and decided upon, or with problematizing the ways in which emergent threatening futures are anticipated, fostered, and pre-empted. Or perhaps more importantly ignored upon us by events- in no small part due to the the forceful cultivation of public doubt, confusion and ignorance, an anti-epistemic praxis dubbed 'agnotology' by Proctor and Schiebinger (2008). At the same time, novel concerns with the predicaments posed by what might be termed a pervasive "subjunctive mood" of the present urban condition are indicative of a more profound mode of engagement with futures.

In this line of thinking Vincanne Adams, Michelle Murphy and Adele Clarke have argued that "one defining quality of our current moment is its characteristic state of anticipation, of thinking and living toward the future" (Adams, Murphy and Clarke, 2009, p. 246). In a similar line Adrian Mackenzie (2013), contends that we seem increasingly to be living in a "regime of anticipation" (Mackenzie, 2013, p. 391). Yet characterisation of contemporary modes of future-orientation as unprecedented may risk overstatement if not considered in the longer durée of historical consciousness, in all the ontological diversity of ways of being in time (Granjou \& Salazar, 2016). Or, as the anthropologists 
Linda Connor and Jon Marshall (2015, p.1) have observed:

A paradox of cultural, social and ethical life in all societies is that is directed towards a future that can never be observed, and never directly acted upon, and yet is always interacting with that social life. As a result, actions depend both on imagination and on a political ontology or sense of being in the world and of the nature of that world.

For Barbara Adam, "the future poses major challenges [to social sciences inquiry] because it lacks the tangible materiality needed for empirical study" (Adam, 2009 p.1). On the other hand, the reason why futures have long eluded social science inquiry and theory is not only methodological but also more deeply epistemological: with their constructivist focus on understanding how human subjects make sense of the world by building intersubjective meanings and institutions, social sciences historically contributed to reinforcing the modern vision of a human-made future. Researching environmental futures requires us instead to destabilize the disciplinary patterns of the social construction of reality in order to confront the autonomous and outside reality of the future (Granjou, 2016, p. 13), and to become more attuned to the fact that humans and societies do not own and shape "their" future alone: environmental futures are definitively "more than human" futures channelled future-making capacities of all the non-human beings, ecological patternings and inhuman material forces of the Earth.

In a $1932 \mathrm{BBC}$ radio broadcast, the science/fiction writer H.G. Wells lamented that there were no 'Professors of Foresight' devoted to the anticipation of technology-driven social change (Slaughter 1989, p.3-4). Tellingly, the petrol-powered automobile was Wells'example. This is of course no longer the case, and beyond academia many 'thought leaders' now make their living as business strategists, offering strategic insights into the future: we need only consider the widespread contemporary fascination with organisational concepts such as innovation, flexibility, disruption, agility and resilience. It is also increasingly the case that natural scientists are called to research in the anticipatory mode, projecting trends from historical facts into imminent future states of the local or planetary environment. For the marine ecologist Roger Bradbury (2012), the Earth's coral reefs are already "zombie ecosystems, neither dead nor truly alive in any functional sense, on a trajectory to collapse within a human generation." Others report that by century's end it will be too hot for the human body to survive summer heat waves in the Middle East and North Africa (Lieleveld et al., 2016), a region long considered the 'cradle of civilisation' in Abrahamic or Eurocentric universal histories. Clearly, the stakes for the political contest over anticipatory visions and knowledges, over action which prepares for or strategically intervenes in the future, could not be higher.

Contemporary methodologies of global, anticipatory social science are routinely traced to the 1940's, when military strategists, government planning agencies and large corporations began devoting substantial resources to organise future-oriented research. The co-emergence of atomic weapons, digital computers, and cybernetic systems-modelling from within the US military industrial complex and early 'think-tanks' such as the Rand Corporation - a hybrid organisation emerging in the interface between the US Air Force and its avionics contractors - that would raise the stakes of geopolitical anticipation to apocalyptic heights. The Cold War strategy of 'maintaining the balance of terror' through MAD (mutually assured destruction) could only be interpreted as the hardest form of anticipatory rationality within an intellectual atmosphere "sleek with dread and heavy with doom" (Mirowski, 2002, p.45).

In the 1960s the Rand Corporation developed the Delphi method, an iterative process of aggregating, refining and statistically analysing expert opinion for long range forecasting and planning purposes (Dalkley, 1967). However it was the work of Rand's civil defence strategist Herman Kahn, which would challenge the US military establishment to systematically 'think the unthinkable' - for example, that wishful thinking, complacent groupthink and miscalculation amongst US military elites might be the cause of total thermonuclear war. Kahn's anticipatory methods of strategic transition to the future would be further developed when he left the military to found the conservative think-tank the Hudson Institute, which drew wide publicity his book The Year 2000, co-authored with Anthony Wiener in 1967. 
In the same year the Shell oil company initiated its 'Year 2000', a project to study the future 'business environment'. The study anticipated turbulent futures for the oil industry, concluding that: "the historical trajectory of year-on-year expansion of the industry could not continue to 1985 , let alone 2000" (Bradfield et al., 2005). In the 1970s, a result of internal dissatisfaction with the corporate planning and strategy arising from its Universal Planning Model, the Shell oil company developed the method of scenario planning, in which multiple possible future scenarios - "anticipated retrospectives" - were creatively imagined, then role-played and ranked by executives in terms of degrees of belief, rather than in terms of mathematical probability. Scholars attribute to this method Shell's relatively agile navigation of the 1970s energy crisis, when from Arab oil exporting nations embargoed US markets. The method of scenario analysis would be taken up not only in conservative military and business circles devoted to securing a future of economic growth, but was also taken up by the Club of Rome. Deploying several scenarios, the Limits to Growth report attempted to model the biophysical interaction between industrial technomass and the Earth 'system' for the century to come (Meadows et al 1972). Anticipatory scenario-modelling became the format organising the reports of the Intergovernmental Panel on Climate Change, of the Millenium Ecosystem Assessment (2005), to say nothing of the mathematical techniques deployed in the financial heights of global power, where the unknowable future values of capital, debt, currency, weather, energy, resources, and political violence are speculatively traded and benchmarked in futures markets, derivative contracts, parametric insurance, and catastrophe bonds (Cooper, 2010).

\section{III- Politics of environmental anticipation: a Special Issue of Futures.}

Science generates anticipation, but remains subject to political and economic anticipation. Command over futures, imaginary, political and geophysical, appears more closely aligned to command over pyrotechnical capital than we might wish. As a consequence we would suggest a distinction not made often enough in contemporary research on anticipation: one between anticipatory action (namely: actions performed so as to alter materially the course of events and thus the possible future) and activities which anticipate (research which merely improves data and produces more accurate means of projecting trends into possible futures). All too clearly, scientific knowledge is not in itself power. Quite the contrary, the politics of environmental anticipation might be said to resolve to the political technologies by which scientific knowledge is neutralized and prevented from having political effects, neutralising attempts at collective anticipatory action to prevent further degradation of ecological order, and naturalizing life on the edge of irreversible chaos as the normal state of things.

The task before us consists in comprehending the temporalities of social-ecological change at a moment when crossing certain biophysical thresholds will likely have disastrous consequences for life on Earth, if interlinked planetary boundaries continue to be irreversibly overstepped (Rockstrom et al., 2009). This points to a radically different way of conceiving futures research. For much of the modern era - as we have argued elsewhere (Walker, 2007; Granjou \& Salazar, 2016) - the future was largely viewed in terms of modernity's human-centred categories of innovation, emancipation, progress and civilization, while nature was irremediably shoved to the realm of the a-historical, understood as a fixed background for the development of society. In this regard much attention in the articles that make up this special issue is placed on the entanglements of humans and environments in ways that create new connections and proximities in a global world, or new ways of making-kin in Donna Haraway's words. In other words we argue that the future cannot be fully addressed without acknowledging those shared futurities of nature-culture entanglements (Granjou \& Salazar, 2016). Not only impending radical environmental changes orient human and non-human beings toward shared destinies. Non-humans (animals, plants, things, matter and ecological and physical forces) themselves instigate change and trigger the advent of unprecedented and partly unpredictable futures. Hence, these emerging concerns with researching human and more-than human futures has also opened up new platforms for a range of anticipatory modes of inquiry ranging, for instance, from accounts of how futures are predicted and projected by algorithms, to how futures are envisioned, imagined, promised and performed according to different affective and sensory coordinates. 
As editors of this special issue on the politics of anticipation we were most interested in questions of knowing and governing environmental futures. But we were also captivated by how, as an affective state, anticipation becomes a performative way of actively orienting oneself temporally, where, as Adams, Murphy and Clarke suggest, anticipation works as a regime of being in time, in which one "inhabits time out of place as the future" (Adams, Murphy and Clarke, 2009, p. 247). This signals the ways in which, at least to a point, anticipation has become a common, lived affect-state of daily life, shaping regimes of self, health, spirituality, but also our relations and entanglements with non-human nature. In other words, anticipation has often acquired epistemic and normative value as a politics of temporality and affect; "a virtue emerging through actuarial saturation as sciences of the actual are displaced by speculative forecast" (Adams, Murphy and Clarke, 2009, p. 247).

To be sure, anticipatory practices have always been part of the risk management techniques and powers of commercial, industrial and state power, capitalist dynamics and subjectivities, but the atomic, genetic, chemical The questions is, how might the forms of environmental anticipation that have proliferated since the 1970s lead to responsibility, and to what extend do we retain the abilitity to respond? How do we resist an immobilising 'regime of anticipation' that preserves immunitiy for organized irresponsibility on an industrial, indeed planetary scale? An extreme pessimism on this point is registered by Charles Thorpe, who puts it this way: "the trajectory of capitalist technology is toward artificial life on a dead planet" (2016, p. 54).

In a different vein, futures geographer Ben Anderson has been influential in framing an approach to explain how futures are "disclosed and related to through statements about the future (styles); rendered present through materialities, epistemic objects and affects (practices); and acted on through specific policies and programmes (logics)" (Anderson, 2010, p. 779). In his outline of three types of anticipatory practices: calculating, imagining and performing futures, each produce different preemptive and precautionary logics. In this case anticipation also has epistemic value because it's about the mutual adjustment between future expectations and contingent present dynamics - as a process through which the present is transformed, intervened in and ultimately governed in the name of the future. Anticipation, as a lived condition or orientation always demands a response in the present; it is about "enacting a future that (hopefully) makes a present that (hopefully) shapes the future" (Wilkie and Michael, 2009, p. 504; see also Alvial-Palavicino 2016). So anticipation is explicitly a taking care of (preparing for) ahead of time (implicit in its etymology). If this is the case it is of upmost importance to find, to create - and fight for - ways of 'imagining the about-to-be-present' (as Anna Tsing notes) in ways that avoid the 'shadow of inevitability' of neoliberal globalization and attend 'to states of emergence - and emergency ... [where] hope and despair huddle together' (2005, p. 269).

Therefore, in this special issue of Futures we wanted to illustrate the multiple ways through which anticipation of environmental futures has come to the fore as a developing field of expertise and practice that is propelling innovative thinking and infrastructures and new ethical issues across the life and earth sciences and in such sectors as biodiversity management, land planning, and ecological engineering. Environmental futures today include perspectives of biodiversity loss, climate change, local and global tipping points and ecological emergencies (Oreskes \& Conway, 2013), as well as new synthetic organisms, artificial biomes, and geo and eco-engineering technologies aiming to secure the resilience of the biosphere and the conditions of human life on Earth. Anticipatory goals and concerns are incorporated within a growing number of fields and sectors of environmental conservation, knowledge, management and innovation (such as: ecology, agronomy, biodiversity management, land use planning, oceanography and microbiology, while scientists, lay people, citizen scientists, artists and activists engage with enduring assessments of the 'not yet' in an attempt to secure forms of nonhuman and human life as we know them today.

As editors of this special issue of Futures our aim was to connect new scholarship across 'epistemic trading zones' bringing into dialogue a range of disciplines including STS, cultural geography, environmental humanities, futures studies, sociology, history, political science and anthropology. Articles build on empirical investigations of a range of sites and infrastructures of environmental anticipation in order to examine the broad reconfiguration of research agendas, environmental 
governance and techno-industrial innovation pathways toward anticipatory and security purposes regarding biodiversity, ecosystems and the biosphere. They reveal insights into the complexities of anticipating the futures of entangled socio-technical-ecological dynamics whereby scientific research, government, industries, markets and civil society produce the future of nature and society in the same movement.

The invitation for contributors was to rethink or reflect on the heuristic value and epistemic value of the notion of anticipation, and to respond to a number of framing questions such as: How are futures brought into the present forms of social organization and praxis? Where does anticipation stop when "second-level" set of associated risks and questionable consequences are produced by anticipatory agendas and technologies themselves? How do technologies of anticipation re-shape environmental issues and politics?

In response, the articles as a whole pay attention to the various, and partly competing, regimes of environmental anticipation enacted by a growing number of scientists, experts, community activists industrials and stake-holders aiming to conserve, restore, manage, secure, optimize and/or reengineer environments and societies. Taken together, these eight contributions examine from a range of disciplinary perspectives the various assemblages of practices, forms of representation and material infrastructures enabling experts and lay people to anticipate, foster, and pre-empt the futures of biodiversity, ecosystems, landscapes and human life and activities in the biosphere, and scrutinize the various politics of anticipation associated. They remind us that it is time for social science to start paying more attention to the future work which is also routinely at play when environmental scientists, experts and managers are faced with the task of making sense of the various dynamics of change and becoming fostered by living beings and the Earth's cycles and exchanges of matter and energy. What is at stake in bringing the social sciences and humanities closer to the increasingly futural orientation of the natural sciences? For the geographer Nigel Clark, we must "begin to think through and not only about nature sciences - but in registers that embellish and exceed what scientists themselves would comfortably articulate" (Clark, 2011, p. 28). The analysis of social organisation can no longer proceed as if it were unnecessary to understand the inhuman future-making capacities and forces of the geosphere which, whilst they operate in the fullness of geological and evolutionary time, we are indelibly, inescapably, and forcefully part of.

Clark's exhortation to take the results of the Earth sciences as ground for the critical analysis of material culture and practices, of the limits of geopoltical agency and our collective temporal prospects represents a challenge to the social theory deployed in the mode of science studies influenced by Bruno Latour. Latour's critics argue that he tends to reduce the politics of science to an incredulity towards "facts", "moderns" and "modernist politics", a post-environmentalism which strays uncomfortably close to the anti-environmentalism of the neoliberal think-tank network (Mirowksi, 2015). In attributing agency to a welter of non-living artefacts and scientific objects in detailed ethnographies of science, Latourian STS has tended to be subversive of our basic confidence in scientific knowledge production, yet this skepticism, which refuses macro-sociological concepts such as 'society', 'capitalism', and 'economy', "has not been directed at capital, power and global inequalities" (Hornborg 2016, p. 8).

This tension between contructivist readings of scientific knowledge production, and the question of environmental science's political consequences resonates throughout the articles of this special issue, in particular in Irus Braverman's article Bleached! The Catastrophe Management of Corals (this issue). Based on participatory observation and in-depth interviews with coral scientists and marine park managers, Braverman shows how corals have emerged as both sign and measure of the imminent catastrophic future of life on Earth. Here the stark image of dead coral, bleached white by unprecedented ocean tempratures, shapes an analytic of catastrophe and closing future horizons where science, conservation management policies, oceans, and inter-species life become entangled in the politics of anticipation. In her study of the "management" of coral reefs by scientists who anticipate their imminent global extinction through catastrophic bleaching events, Braverman reveals the significance of algorithmic models and elaborate temporal analyses in marine conservation biology for 
"knowing bleaching". Braverman also poignantly uncovers the ways in which scientific knowledge is often 'managed', neutralized and prevented from having appropriate political consequences. Neoliberal governments continue to forcefully brush aside obstacles to the expansion of the fossil fuel sector in the name of energy for economic growth - the very process making the oceans an inhospitable environment to the Earth's most diverse, productive and abundant ecosystems. Scientific labour is directed into further refining anticipatory methodologies, or diverted into imagining prosthetic methods of coral restoration which have little hope of success.. Braverman's account of an oceanic catastrophe to come, indeed one well underway, strikes as hard as the hell of Hobbes and Hegel: an already advanced catastrophe almost certainly far beyond the scope of any precautionary policy or anticipatory action.

In his article Emptying the future: On the environmental politics of anticipation, (this issue) Christopher Groves examines anticipation as material-discursive practices. As a capacity or characteristic, he argues, anticipation not only manifests through representations, even if these representations of the 'not yet' are performative in nature, but also comprise material capacities, which are always simultaneously "technological, biophysical and affective in nature". This is an interesting move as it pushes us - as Groves rightly observes - to extend our conceptual vocabularies to encompass the materiality of anticipation. In his attempt to theorize the entanglement of matter and meaning, Groves thus focuses on an analysis of the politics of anticipation of energy infrastructure planning in the UK to illustrate how understanding anticipation as a capacity dependent on a heterogeneous set of human and more-than human capabilities enables a better comprehension of the deep sense in which environmental politics is always a politics of the future.

In his article Anticipatory Policymaking in Global Venues: Policy Change, Adaptation, and the UNFCCC, (this issue) Rob DeLeo accounts for the anticipatory character of climate governance, building on a case study of the United Nations Framework Convention on Climate Change (UNFCCC). Far from the depiction of government as an inherently reactive entity which is often found in the literature, Rob DeLeo explores what happens to policymaking patterns when they become anticipative in order to tackle evolving future horizons, such as the complicated time horizons at stake with the partial shift from climate mitigation, which aims to reverse or at least mitigate warming by reducing greenhouse gas emissions, to climate adaptation, which strives to reduce social, economic, physical vulnerabilities in the face of anever-warming planet. The article emphasizes the ways in which the governance of emerging hazards differs in some important ways from post-disaster policymaking and documents how climate governance "is shaped by a combination of indicators, planning, institutions, and narratives describing constantly evolving temporal horizons".

By documenting two techno-burial practices - the long-term disposal of industrial and toxic waste underground and the sequestration of carbon in soil and terrestrial sinks - Matthew Kearnes and Lauren Rickards explore contemporary investments in the underground as being overcoded with an anticipation of hoped-for environmental and human futures. In their paper Earthly Graves for Environmental Futures: techno-burial practices, (this issue) Kearnes and Rickards emphasize how the intensification of mining and extractive processes relies on the development of promises of deep burial that requires the re-imagination of the underground as a stable site shaped by technologies of material and social transparency. In a parallel with the funerary rituals deployed in order to achieve death as a separation from the living, they propose to pay more attention to the contemporary subterranean politics and how it sustains continuing hopes for an ecological modernity relying on the expected burial of the remains of environmental pasts. Strikingly, they highlight how the instability of the subsurface revealed by recent scientific research eventually entails the continuing generation of a fraught, "zombie waste".

In their paper MELiSSA the minimal biosphere: human life, waste and refuge in deep space, (this issue) Jeremy Walker and Céline Granjou develop a critical account of MELiSSA (Micro-Ecological Life Support System Alternative), a long-term European Space Agency program. This program aims to construct autonomous habitats in deep space, supplying astronauts with fresh air, water and food through continuous microbial recycling of human wastes. The article considers how anticipated 
futures of space travel and environmental survival are materialized in the project of engineering the minimal biosphere capable of reliably sustaining human life: a human/microbe association with the fewest possible species. This is a technical problematic that mirrors our situation here on Earth, as the unravelling and disorganisation of global ecosystem functions (eg. the cycling of carbon, nitrogen and phosphorus) is simultaneously a cause and effect of mass extinctions of species. MELiSSA's sewagecomposting technology presents a formidable "bottle-neck" for the construction of the minimal biosphere, highlighting our ultimate dependence on irreducible complex microbial communities (here, those connecting the human gut to the composting processes of soil). MELiSSA is located within a wider genealogy of colonization bio-infrastructures and 'greenhouse geopolitics', now culminating in a range of space refugia projects imagined in the prospect that the Earth might cease to function as the only biosphere capable of supporting civilization.

In Martin Skrydstrup's paper Envisioning the Future by Predicting the Past: Proxies, Praxis and the Politics of Prognosis in Paleoclimatology (this issue) the attention shifts to the future of Greenland where he develops an ethnographic based inquiry of Danish ice core research to account for how technologies of anticipation within paleoclimatology relate to contemporary modes of envisioning environmental futures. For Skrydstrup, ice core science gravitates towards what he terms "analogue anticipation" between deep pasts and probable futures and where ice core research works as a sort of vantage point to discuss the political nature of climate science from the perspective of proxies and prognosis.

In her paper, Speculative promise as a driver in climate engineering research: The case of Paul Crutzen's back-of-the-envelope calculation on solar dimming with sulfate aerosols, (this issue) Mieke Van Hemert turns the attention to climate engineering to show how the ontological commitments underlying the desire to control climate stands in plain contrast to stances which do not see humans as masters of a calculable cosmos. The article focuses on Paul Crutzen's calculation on emulating Mount Pinatubo and scrutinized the way it convinced atmospheric scientists and their funders to conduct and support research on stratospheric climate engineering with sulfate aerosols. Van Hemert shows how speculation continues to be a strong driver of climate engineering research: even though fundamental objections were made to Crutzen' proposal by further scientific approaches producing much less promising calculations, the initial claims kept re-appearing in the hope for eventually 'fixing' the climate predicament. Climate scientists who have been contrarian to Crutzen's climate paradigm through the constant invocation of complex feedbacks and hinting at irreducible unknowns, appear to be committed to what she terms "a rather more humble spectrum of stances", and should inspire us for adopting "a politics of anticipation which does away with grandiose wishes and engages in discussing and altering 'what is happening', given that we are historically situated, vulnerable but not politically powerless humans".

Finally, in the last paper of the collection, Declan Kuch addresses projects of carbon dioxide $\left(\mathrm{CO}_{2}\right)$ capture and storage (CCS) promoted by coal, oil and gas industry experts and their allies as an integral part of climate change mitigation efforts and how initiatives and programs for their scaling-up have often stalled. Unpacking the ways CCS technologies have become conceived as a necessary solution in relation to the major influence of the prism of oil and gas expertise, he shows how oil and gas experts' claims for epistemic authority and knowledge hierarchy have led to framing public opposition itself as an issue of risk and acceptance. While "such a mentality brings its own blindspots beyond the frequent spills, leakages and explosions in oil and gas projects", CCS promises also contribute to framing the problem of climate change "as merely one amenable to technical fix through ever more investment". Unpacking issues of procedural and epistemic (in)justice at stake in mainstream conceptions of CCS prospects and particularly their lack of consideration for the results of seismic sciences, he emphasizes the serious limits weighing on any future possibility of CCS ethical governance.

The eight articles in this Special Issue of Futures all illuminate the intricate, complicated and often obscure ways in which futures are continually being told, traded, tamed, promised, transformed and traversed (Adam \& Groves, 2007); or how they are calculated, imagined and performed giving way to 
differing, varying and often contested modes of pre-emption, prefiguration, and preparedness (Anderson, 2010). In their own way they all show how futures are made possible, probable and preferred as much as they are forged, negotiated, colonized and tamed (Felt, 2011, p. i). In assembling this array of thinkers and scholars we want to make a statement to note the urgent need for thinking more seriously about the political relevance and implications of futures studies work, including how to instigate and support more effective public processes at the local level to build awareness, capacity, and agency on global environmental change, in ways that better inform and support planning and decision-making. If, as Wendell Bell once noted, the study of the future represents for social researchers both a scheme for organizing and analysing the social realities that confront us, and a way of orienting and directing our efforts (Bell, 2005), we can't turn a blind eye to the fact that we are living through a momentous time - the Anthropocene as some would name it - in which academic scholarship cannot abstain from instigating a change in the way we are in this world, or in the plurality of ways through which we make and unmake futures that impact on all life on this planet. This question of the political relevance and impact beyond academia is recognised by Stuart McLean, who drawing on Nigel Clark reminds us of the need for humans "as sojourners on a volatile planet, to acknowledge and respect the wayward potentialities of the other-than-human presences by which they are surrounded, and upon which they depend for their continued survival" (McLean 2016, no page number) before human interventions produce tipping points and feedback effects in excess of anything we are able to calculate or predict.

\section{References}

Adam, B., 2009. Future Matters: Challenge for Social Theory and Social Inquiry, Keynote address to Italian Sociological Association Conference, Future Matters for Social Theory, 29 October 2009, Cagliari University, Sardinia: http://www.cardiff.ac.uk/socsi/futures/briefings.html\#working

Adam, B. \& Groves, C. (2007). Future matters: Action, knowledge, ethics. Leiden: Brill.

Adams, V., M. Murphy and A. E. Clarke (2009). 'Anticipation: Technoscience, life, affect, temporality'. Subjectivity 28 (1), 246-265.

Alvial-Palavicino, C. (2016): The Future As Practice. A Framework to Understand Anticipation in Science and Technology. TECNOSCIENZA: Italian Journal of Science \& Technology Studies 6 (2) $135-172$

Anderson, B. (2010). Preemption, precaution, preparedness: Anticipatory action and future geographies. Progress in Human Geography, 34(6), 777-798.

Andrews, J.K., Armey, D., Barnes, F., et. al (1990) The vision thing: conservatives take aim at the '90s. Policy Review, 52: 38-43.

Bell, Daniel (1976) The Coming of Post-Industrial Society: a Venture in Social Forecasting. New York: Basic Books.

Bell, 2005. Creativity, Skepticism and Visioning the Future, Futures 37(5), 429-432

Blumenberg, H. (1985). The legitimacy of the modern age, (trans. Wallace, R.) Massachusetts: MIT Press.

Bradfield, R., Wright, G., Burt, G., Cairns, G., \& Van Der Heijden, K. (2005). The origins and evolution of scenario techniques in long range business planning. Futures, 37(8), 795-812.

Bradbury, R. (2012). A world without coral reefs. New York Times, July 13, 2012.

Clark, N. (2011). Inhuman Nature: Sociable Life on a Dynamic Planet. London: Sage. 
Connor, L. \& Marshall, J. (2015). Ecologies, mythologies and ontologies of possible futures. In Connor, L. \& Marshall, J. (Eds.) Environmental change and the world's futures: ecologies, ontologies and mythologies. (pp. $1-14)$. Sydney: Routledge.

Cooper, M. (2010). Turbulent worlds: financial markets and environmental crisis. Theory, Culture \& Society, 27 (2-3), 167-190.

Dalkley, N. (1967). Delphi. Paper prepared for the Second Symposium on Long Range Forecasting and Planning, Alamogordo, New Mexico. Santa Monica: RAND. http://www.rand.org/pubs/papers/P3704.html

Derrida, J. (1984). Of an apocalyptic tone recently adopted in philosophy. Oxford Literary Review, 6(2), 3-37.

Davis, M. (2006). Planet of slums. London: Verso.

Felt, U. (2011). Welcome Address "Geographies of Technoscientific Futures: Anticipatory Work, Emerging Technologies and Technopolitical Cultures". Governing Futures International Conference: Imagining, Negotiating, Taming Emerging Technosciences. University of Vienna, 22 September 2011.

Granjou, C. (2016) Environmental Changes—Sociology of the Futures. London: Wiley/Iste,.

Granjou, C., \& Salazar, J. F. (2016). Future. Environmental Humanities, 8(2), 240-244.

Haraway, D. (2008) When Species Meet. Minneapolis: University of Minnesota Press.

Hornborg, A. (2001). The power of the machine: global inequalities of technology, economy, and environment. Lanham: Altamira.

De Jouvenel, B. (1972). The art of conjecture. London: Weidenfeld and Nicolson.

Kahn, H. \& Wiener, A. J. (1967). The next thirty-three years: A framework for speculation. Daedalus, 96(3), 705-732.

Kaiser, D. \& Wasserman, L. (2016) The Rockefeller Family Fund vs. Exxon. New York Review of Books, Dec 8, 2016. http://www.nybooks.com/articles/2016/12/08/the-rockefeller-family-fund-vsexxon/

Koyré, A. (1957) From the closed world to the infinite universe. Baltimore: Johns Hopkins Press.

Koyré, A. (1973). The astronomical revolution. London: Methuen.

Lelieveld, J., Proestos, Y., Hadjinicolaou, P., Tanarhte, M., Tyrlis, E., Zittis, G. (2016). Strongly increasing heat extremes in the Middle East and North Africa (MENA) in the 21st century. Climatic Change, 137(1), 245-260

Layzer, J.A (2012) Open for business: conservatives' opposition to environmental regulation. Masachusetts: MIT Press.

Lovelock, J. E., \& Margulis, L. (1974). Atmospheric homeostasis by and for the biosphere: the Gaia hypothesis. Tellus, 26(1-2), 2-10.

Mackenzie, A. (2013) Programming Subjects in the Regime of Anticipation: Software Studies and Subjectivity. Subjectivity 6 (4), 391-405. 
Malm, A. (2016). Fossil capital: the rise of steam power and the roots of global warming. London: Verso.

Margulis, L. \& Lovelock, J. (1974). Biological modulation of the Earth's atmosphere. Icarus, 21, 471489.

Mead, M. (1971). A note on contributions of anthropology to the science of the future. Human Futuristics (Social Science Research Institute). Honolulu: University of Hawaii.

Meadows, D. H., Meadows, D. H., Randers, J., \& Behrens III, W. W. (1972). The limits to growth: a report to the club of Rome. New York: Universe Books.

McLean, S. (2016) Nature. Theorizing the Contemporary, Cultural Anthropology website, January 21, 2016. https://culanth.org/fieldsights/789-nature

Mesarovic, M., \& Pestel, E. (1974). Mankind at the turning point: the second report to the Club of Rome. New York: E.P. Dutton.

Millenium Ecosystem Assessment (2005). Ecosystems and human well-being: Biodiversity synthesis, Washington, DC.: World Resources Institute.

Mirowski, P. (2002) Machine dreams: economics becomes a cyborg science. Cambridge MA: Cambridge University Press.

Mitchell, T. (2011). Carbon democracy: Political power in the age of oil. London: Verso.

Nef, J. (1964) The conquest of the material world. Chicago: University of Chicago Press.

Oreskes, N., \& Conway, E. M. (2013). The collapse of Western Civilization: a view from the future. Daedalus, 142(1), 40-58.

Pink, S., \& Salazar, J.F. (2017). Anthropologies and futures: Setting the agenda. In J. F Salazar, S.Pink, A. Irving \& J. Sjøberg (Eds.) Anthropologies and Futures: Researching Emerging and Uncertain Worlds. London: Bloomsbury.

Proctor, R., \& Schiebinger, L. L. (Eds.). (2008). Agnotology: The making and unmaking of ignorance. Redwood City: Stanford University Press.

Rabinow, P. (2003) Anthropos today: reflections on modern equipment. Princeton, NJ: Princeton University Press.

Rockström, Johan, Will Steffen, Kevin Noone, Åsa Persson, F. Stuart Chapin, Eric F. Lambin, Timothy M. Lenton et al (2009). A safe operating space for humanity. Nature 461, no. 7263, 472-475.

Rockström, Johan, Hans Joachim Schellnhuber, Brian Hoskins, Veerabhadran Ramanathan, Peter Schlosser, Guy Pierre Brasseur, Owen Gaffney et al. (2016). "The world's biggest gamble." Earth's Future, 4(10) , 465-470.

Rostow, W. W. (1960). The stages of growth: A non-communist manifesto. Cambridge University Press.

Slaughter, R. (1989) (ed) Studying the future, Australian Bicentennial Authority/Commission For the Future, Melbourne. 
Thorpe, C. (2016). Artificial life on a dead planet. In Necroculture (pp. 53-91). Palgrave Macmillan US.

Toffler, A., 1970. Future Shock. New York: Amereon

Tsing, A. L., 2005. Friction: An Ethnography of Global Connection. Princeton, NJ:

Princeton University Press.

Valentine, D. (2015). What happened to the future? Anthropology Now, 7(1), 110-120.

Walker, J. “Economy of Nature.” PhD diss., University of Technology Sydney, 2007.

Wilkie A. \& M. Michael. (2009). Expectation and Mobilisation: Enacting Future Users. Science, Technology, \& Human Values (4), 502-522 